\title{
Tezek Külü İkameli Çimento Harçlarının Mühendislik Özellikleri
}

\section{Engineering Features of Dung Ash Substituted Cement Mortars}

\author{
Yusuf Tahir Altunc1 ${ }^{1 *}$, Cenk Öcal ${ }^{2}$ \\ Geliş / Received: 06/11/2020 \\ Revize / Revised: 12/02/2021 \\ Kabul / Accepted: 18/02/2021

\section{ÖZ}

Bu çalışmada tezek külü ikameli çimento harçlarının mühendislik özellikleri incelenmiştir. İnekten elde edilen tezek malzemesi $400{ }^{\circ} \mathrm{C}$ de kalsine edilerek tezek külü haline getirilmiş ve CEM I 42.5 R tipi çimento yerine ağırlıkça $\% 0, \% 2, \% 4, \% 6, \% 8$ ve $\% 10$ oranlarında ikame edilerek karışımlar hazırlanmıştır. Hazırlanan karışımların; priz süreleri, genleşmeleri, yayılma çapları, birim hacim ağırlıkları ile 2 ve 28 günlük eğilme ve basınç dayanımları belirlenmiştir. Sonuç olarak ikame oranı artışı ile priz sürelerinin uzadığı, yayılma çaplarının, birim hacim ağırlıklarının, eğilme ve basınç dayanımlarının azaldığı belirlenmiştir. Ayrıca tezek külünün portland çimentosu yerine ağırlıkça $\% 8$ oranına kadar ikame edilmesinin yapılan deneyler açısından performansı olumsuz etkilemediği belirlenmiştir.

Anahtar Kelimeler- Kalsinasyon, Tezek Külü, İkameli Çimento, Fiziksel ve Mekanik Özellikler

\begin{abstract}
In this study, engineering features of dung ash substituted cement mortars were investigated. Cow dung material was calcined at $400{ }^{\circ} \mathrm{C}$ and turned into dung ash, and the mixtures were prepared by substituting $0 \%, 2 \%, 4 \%$, $6 \%, 8 \%$, and $10 \%$ by weight instead of CEM I $42.5 \mathrm{R}$ type cement. Setting times, expansions, spreading diameters, unit weight and bending, and compressive strengths of 2 and 28 days of prepared mixtures were determined. As a result, with the increase in the rate of substitution; it was determined that setting times were longer, spreading diameters, unit weight, bending, and compressive strengths decreased. In addition, it was determined that the substitution of dung ash up to $8 \%$ by weight instead of Portland cement did not affect the performance negatively in terms of the experiments.
\end{abstract}

\section{Keywords-Calcination, Dung Ash, Substitute Cement, Physical and Mechanical Features}

\footnotetext{
1*Sorumlu yazar iletișim: yusufaltunci@isparta.edu.tr (https://orcid.org/0000-0002-5418-7742)

Inşaat Bölümü, Teknik Bilimler Meslek Yüksekokulu, Isparta Uygulamalı Bilimler Üniversitesi, Çünür, Isparta 2iletișim: cenkocal@isparta.edu.tr (https://orcid.org/0000-0002-1407-7637)

İnşaat Mühendisliği Bölümü, Teknoloji Fakültesi, Isparta Uygulamalı Bilimler Üniversitesi, Çünür, Isparta
} 


\section{I.GİRIŞ}

Çimento üretimi için; maden ocaklarından temin edilen kalker, kil, demir cevheri ve alçıtaşı maddelerine ihtiyaç vardır [1]. Farin döner firınlarında yüksek sıcaklıklarda ergitilen bu maddeler çimentonun ana ham maddesi olan klinkeri oluşturmaktadır. Yüksek sıcaklığın etkisiyle oluşan bu süreçte karbondioksit $\left(\mathrm{CO}_{2}\right)$ gazları ve sera gazları açığa çıkmakta ve bu gazlar hava kirliliğine neden olmaktadır. Klinkerin gerek üretim aşamasında çevreye verdiği zararı azaltmak için gerekse de klinkerin ana hammadde kaynaklarının hızla tükenmesinin önüne geçebilmek adına alternatif olarak yerel ve fazla miktarda bulunan, ekonomik ve çevreci malzeme arayışları sürmektedir [1,2]. Tezek külü de bu alternatif malzemelerden bir tanesidir. Tezek dünyanın birçok yerinde gübre ve yakıt olarak kullanılmaktadır [3]. Tezek malzemesinin yüksek sıcaklık firınlarında kalsine edilmesi sonucunda üretilen tezek külünün, çimento ve beton içerisinde kullanılabilirliğine yönelik çalışmalar ise devam etmektedir.

Konu ile ilgili olarak; Ojedokun vd. [4], çalı̧̧malarında tezek külünü çimento yerine $\% 10, \% 20$ ve $\% 30$ oranlarında ikame ederek 40-100 mm aralığında yayılma çapına sahip ve 28 günlük basınç dayanımı 6.00-21.33 $\mathrm{N} / \mathrm{mm}^{2}$ aralığında olan betonlar üretmişler ve tezek külünün çimento içerisinde $\% 10$ oranına kadar kullanılmasını önermişlerdir. Venkatasubramanian vd. [5], çalışmalarında tezek külünü çimento yerine $\% 2.5, \% 3$ ve \%3.5 oranlarında ve hindistan cevizi lifini de lif katkı olarak \%1 oranlarında ikame ederek beton karışımları oluşturmuşlar ve tezek külü ve hindistan cevizi lifi ikamesi ile basınç dayanımı ve eğilme dayanımı performanslarının $\% 50$ ila $\% 70$ aralığında arttığını gözlemlemişlerdir. Sruthy vd. [6], çalışmalarında, tezek külünü çimento yerine $\% 6, \% 8, \% 10, \% 12$ ve $\% 14$ oranlarında, cam lifini de lif katkı olarak $\% 0.5$ oranlarında ikame ederek, \%0.5 - \%0.7 aralığında kimyasal katkı kullanarak betonlar üretmişler ve \%8'e kadar tezek külü ikamesinin betonun basınç dayanımını arttırdığını belirlemişlerdir. Familusi vd. [7], çalışmalarında tezek külünü çimento yerine $\% 5, \% 10, \% 15, \% 20$ ve $\% 25$ oranlarında ikame ederek, 0.55 su/çimento oranında beton bloklar üretmişler ve $\% 15$ 'e kadar tezek külü ikamesi ile üretilen beton blokların Nijerya Endüstri Standartlarını karşıladığını tespit etmişlerdir. Kumar [8], çalışmasında uçucu külü ve tezek külünü çimento yerine değişik oranlarda ikame ederek farklı oranlarda karışımlar üretmiş ve \%10 uçucu kül - \%5 tezek külü ikameli karışımlarda en yüksek basınç dayanımına ulaşarak, uçucu kül ve tezek külü yüzdesi arttıkça işlenebilirliğin azaldığını ve priz sürelerinin uzadığını tespit etmiştir. Szymajda vd. [9], 2019 yılı Ocak ve Haziran ayları arasında temin ettikleri tezek atığını, yakma işlemine tabi tutarak tezek küllerinin kimyasal bileşimlerini ve karakteristik erime sıcaklıklarını belirlemişlerdir.

$\mathrm{Bu}$ çalışmada, tezek atığ $400{ }^{\circ} \mathrm{C}$ de kalsine edilerek tezek külü haline getirilmiş ve CEM I $42.5 \mathrm{R}$ tipi çimento yerine $\% 0, \% 2, \% 4, \% 6, \% 8$ ve $\% 10$ oranlarında ikame edilerek karışımlar hazırlanmıştır. Hazırlanan karışımların; priz süreleri ve genleşme tayinleri, yayılma çapları, birim hacim ağırlıkları ile 2 ve 28 günlük eğilme ve basınç dayanımları belirlenmiştir.

\section{MATERYAL VE METOD}

\section{A. Materyal}

Karışımların hazırlanmasında $3.12 \mathrm{~g} / \mathrm{cm}^{3}$ özgül ağırlığında CEM I $42.5 \mathrm{R}$ tipi çimento, $200 \mu$ m'luk elekten elenerek kullanılan $2.52 \mathrm{~g} / \mathrm{cm}^{3}$ özgül ağırlığında ve $3300 \mathrm{~cm}^{2} / \mathrm{g}$ blaine özgül yüzey alanına sahip tezek külü, CEN standart kumu ve şebeke suyu kullanılmıştır. CEM I 42.5 R tipi çimentonun kimyasal özellikleri Tablo 1'de, tezek külünün kimyasal özellikleri ise Tablo 2'de verilmiştir. Tezek külü; Isparta yöresinde yetiştirilen ineklerden elde edilen tezek atığının etüvde değişmez ağırlığa gelinceye kadar kurutulmasından sonra (Şekil 1a), yüksek sıcaklık firınında $400{ }^{\circ} \mathrm{C}$ de kalsine edilmesiyle elde edilmiştir (Şekil 1b).

Tablo 1. CEM I 42.5 R tipi çimentonun kimyasal özellikleri

\begin{tabular}{ccccccccc}
\hline $\mathbf{S i O}_{2}$ & $\mathrm{Al}_{2} \mathbf{O}_{3}$ & $\mathrm{Fe}_{2} \mathbf{O}_{3}$ & $\mathbf{C a O}$ & $\mathbf{M g O}$ & $\mathbf{S O}_{3}$ & $\mathbf{K}_{2} \mathbf{O}$ & $\mathbf{N a}_{2} \mathbf{O}$ & Kuz. Kay. \\
\hline 20.31 & 4.54 & 3.47 & 63.55 & 1.51 & 2.75 & 0.80 & 0.87 & 2.80 \\
\hline
\end{tabular}

Tablo 2. Tezek külünün kimyasal özellikleri

\begin{tabular}{ccccccccccc}
\hline $\mathrm{SiO}_{2}$ & $\mathrm{Al}_{2} \mathbf{O}_{3}$ & $\mathbf{F e}_{2} \mathbf{O}_{3}$ & $\mathbf{C a O}$ & $\mathbf{M g O}$ & $\mathbf{S O}_{3}$ & $\mathbf{K}_{2} \mathbf{O}$ & $\mathbf{N a}_{2} \mathbf{O}$ & $\mathbf{P}_{2} \mathbf{O}_{5}$ & $\mathbf{M n}_{2} \mathbf{O}_{5}$ & $\mathbf{T i O}_{2}$ \\
\hline 68.17 & 4.47 & 3.16 & 13.01 & 2.19 & 1.33 & 2.85 & 0.55 & 1.42 & 0.62 & 0.37 \\
\hline
\end{tabular}




\begin{tabular}{|c|c|c|}
\hline & $\begin{array}{l}\text { BŞEÜ Fen Bilimleri Dergisi } \\
8(1), 24-31,2021\end{array}$ & $\begin{array}{r}\text { BSEU Journal of Science } \\
\text { https://doi.org/10.35193/bseufbd } 822474\end{array}$ \\
\hline $\begin{array}{l}\text { KSEYH EDEBALI } \\
\text { ERSITES }\end{array}$ & & 2458-7575 (https://dergipark.org.tr/tr/pub/bseufbd) \\
\hline
\end{tabular}

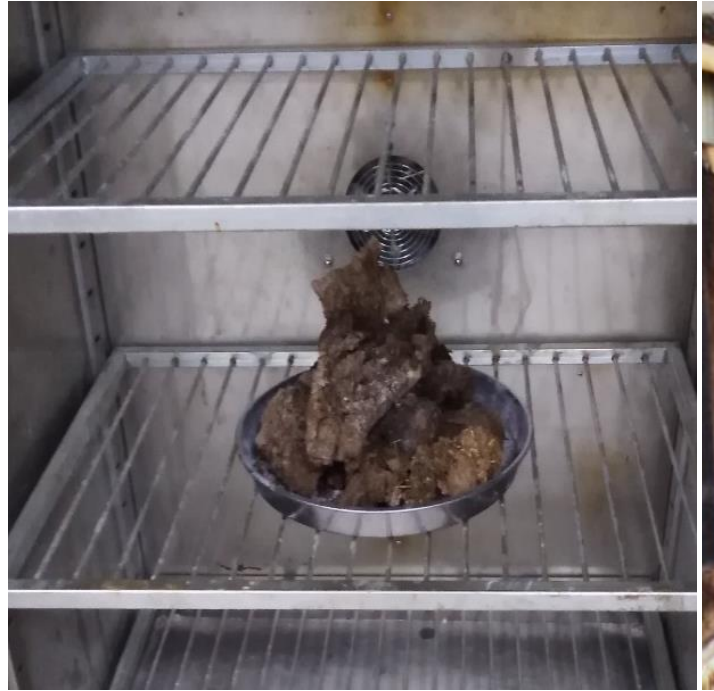

a) Tezeğin etüvde kurutulması

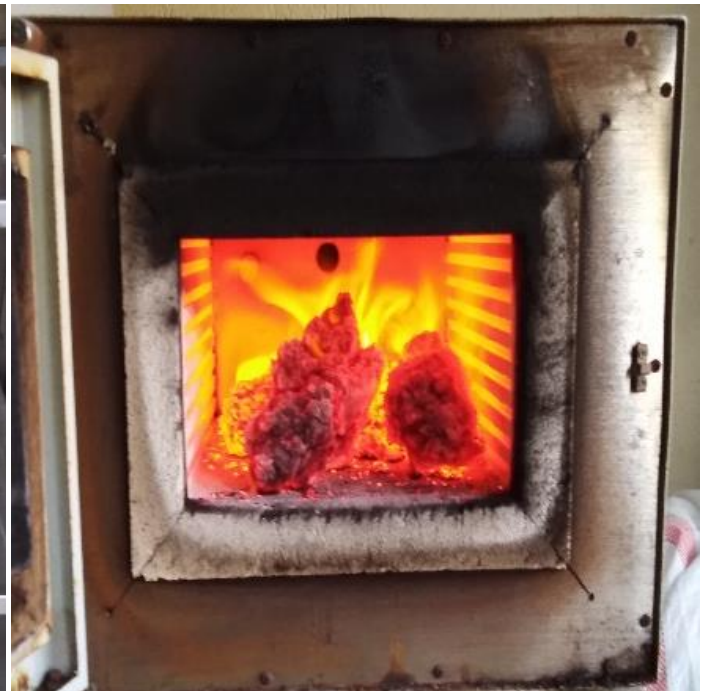

b) Tezeğin kalsine edilmesi

Şekil 1. Tezek külünün elde edilmesi

\section{B. Metod}

Tezek külü ikameli çimento hamurlarının su ihtiyacı değerleri, priz süreleri ve genleşme tayinleri TS EN 196-3 standardına göre belirlenmiştir [10]. Çimento hamuru karışım ve su ihtiyacı oranları Tablo 3' de verilmiştir.

Tablo 3. Tezek külü ikameli çimento hamurlarının su ihtiyacı ve karışım oranları

\begin{tabular}{cccc}
\hline $\begin{array}{c}\text { Karışım } \\
\text { kodu }\end{array}$ & $\begin{array}{c}\text { Çimento } \\
(\boldsymbol{\%})\end{array}$ & $\begin{array}{c}\text { Tezek külü } \\
(\boldsymbol{\%})\end{array}$ & $\begin{array}{c}\text { Su } \\
(\boldsymbol{\%})\end{array}$ \\
\hline TO & 100 & 0 & 29.7 \\
T2 & 98 & 2 & 29.9 \\
T4 & 96 & 4 & 30 \\
T6 & 94 & 6 & 30.4 \\
T8 & 92 & 8 & 30.5 \\
T10 & 90 & 10 & 30.9 \\
\hline
\end{tabular}

Tezek külü CEM I 42.5 R tipi çimento yerine \%0, \%2, \%4, \%6, \%8 ve \%10 oranlarında ikame edilerek tezek külü ikameli çimento harç karışımları hazırlanmıştır. Karışıma giren kum ve su miktarı tüm numunelerde sabit tutulmuştur. Karışım ile ilgili bilgiler Tablo 4' de verilmiştir.

Tablo 4. Tezek külü ikameli çimento harçlarının karışım bilgileri

\begin{tabular}{ccccc}
\hline $\begin{array}{c}\text { Karışım } \\
\text { kodu }\end{array}$ & $\begin{array}{c}\text { Çimento } \\
(\mathbf{g})\end{array}$ & $\begin{array}{c}\text { Tezek külü } \\
(\mathbf{g})\end{array}$ & $\begin{array}{c}\text { Kum } \\
(\mathbf{g})\end{array}$ & $\begin{array}{c}\text { Su } \\
(\mathbf{g})\end{array}$ \\
\hline TO & 450 & 0 & 1350 & 225 \\
T2 & 441 & 7.27 & 1350 & 225 \\
T4 & 432 & 14.54 & 1350 & 225 \\
T6 & 423 & 21.81 & 1350 & 225 \\
T8 & 414 & 29.08 & 1350 & 225 \\
T10 & 405 & 36.35 & 1350 & 225 \\
\hline
\end{tabular}




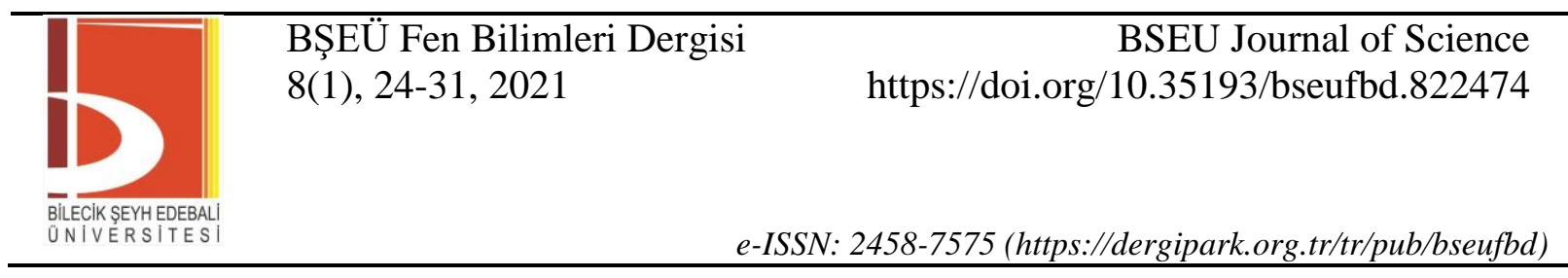

Tezek külü ikameli çimento harçlarının üretimleri TS EN 196-1 [11] standardına göre yapılmıştır. Üretilen numunelerin ilk olarak TS EN 1015-3 [12] standardına göre yayılma tablası yayılma çapı değerleri ölçülmüş ardından, tezek külü ikameli çimento harçları TS EN 196-1 [11] standardına göre 4x4x16 cm boyutlu kalıplara doldurulmuş ve 24 saat sonra kalıptan çıkartılarak kür havuzunda deney gününe kadar bekletilmiştir. Deney günü gelen sertleşmiş harç numunelerinin önce birim hacim ağırlıkları belirlenmiş, ardından TS EN 196-1 [11] standardına göre 2 ve 28 günlük eğilme ve basınç dayanımı deneyleri yapılmıştır.

\section{III.ARAŞTIRMA BULGULARI}

Tezek külü ikameli çimento hamurlarının TS EN 196-3 [10] standardına göre Le Chatelier halkaları kullanılarak yapılan genleşme deney sonuçları Şekil 2'de verilmiştir.

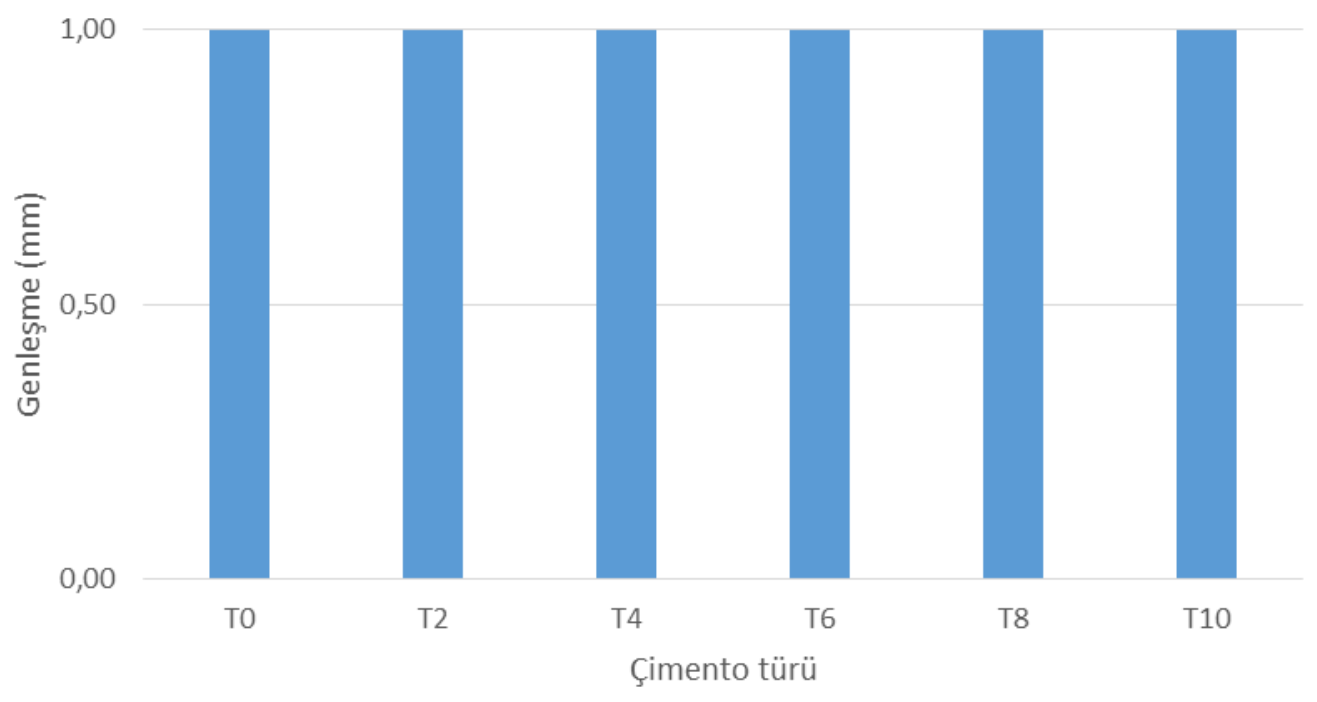

Şekil 2. Tezek külü ikameli çimento hamurlarının genleşme değerleri

Tezek külü ikameli çimento numunelerinin içerisinde bulunan serbest $\mathrm{CaO}$ ve $\mathrm{MgO}$ 'in su ile reaksiyona girmesi sonucunda oluşabilecek olası genleşme miktarının TS EN 197-1 [13] standardına göre 10 mm'nin altında olması gerekmektedir. Yapılan çalışma sonucunda genleşme değerlerinin sınır değeri aşmadığı gözlemlenmiştir. Tezek külü ikameli çimento hamurlarının TS EN 196-3 [10] standardına göre yapılan priz başlangıç ve priz sonu süreleri Şekil 3'de verilmiştir.

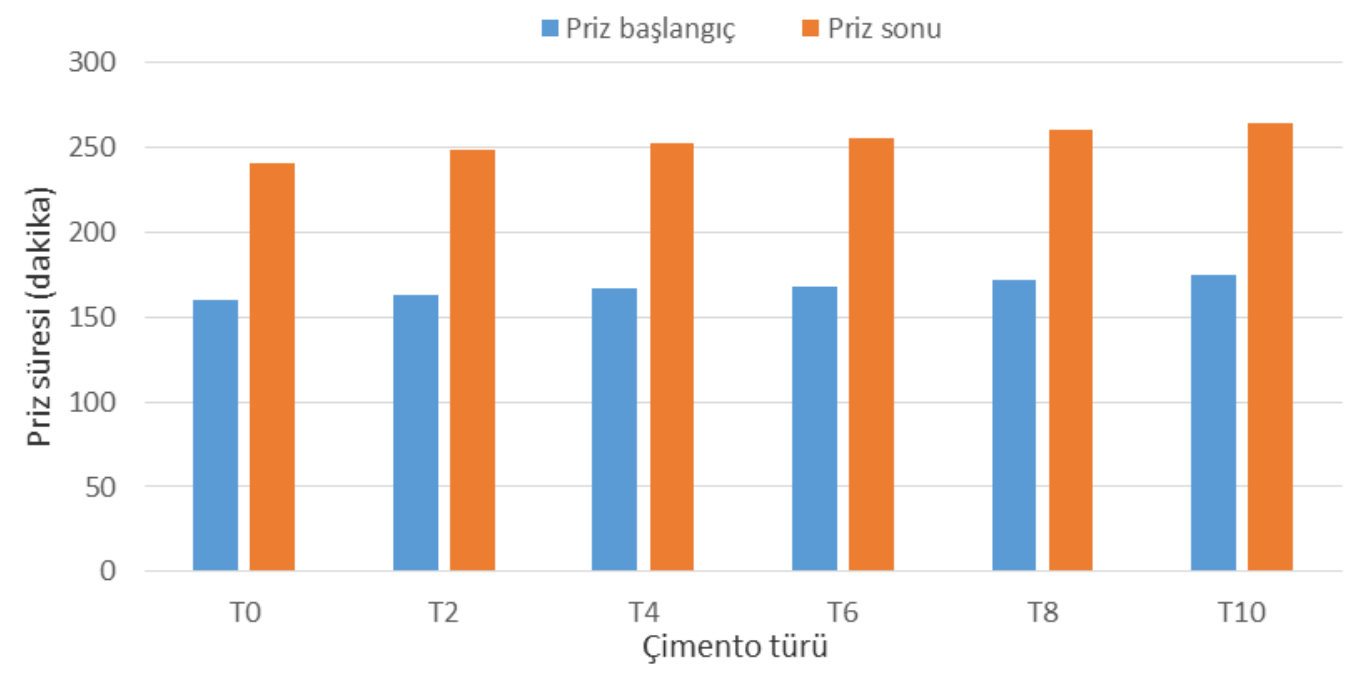

Şekil 3. Tezek külü ikameli çimento hamurlarının priz süreleri 
Priz başlangıç ve priz bitiş sürelerinin sırasıyla $\mathrm{T} 10>\mathrm{T} 8>\mathrm{T} 6>\mathrm{T} 4>\mathrm{T} 2>\mathrm{T} 0$ şeklinde sıralandığ gözlemlenmiştir. Tezek külü ikamesi ile tüm numunelerin priz başlangıç ve priz bitiş sürelerinin uzadığı tespit edilmiştir. Bu sonuç daha önceden yapılan benzer çalışmalar ile örtüşmektedir $[8,14]$. Bununla birlikte tezek külü ikameli tüm numunelerin priz başlama sürelerinin, TS EN 196-3 [10] standardında verilen (priz başlangıç için en az 60 dakika, priz sonu için en çok 600 dakika) sınır değerler içerisinde kaldığı belirlenmiştir. Tezek külü ikameli çimento harçlarının TS EN 1015-3 [12] standardına göre yapılan yayılma tablası yayılma değerleri Şekil 4'de verilmiştir.

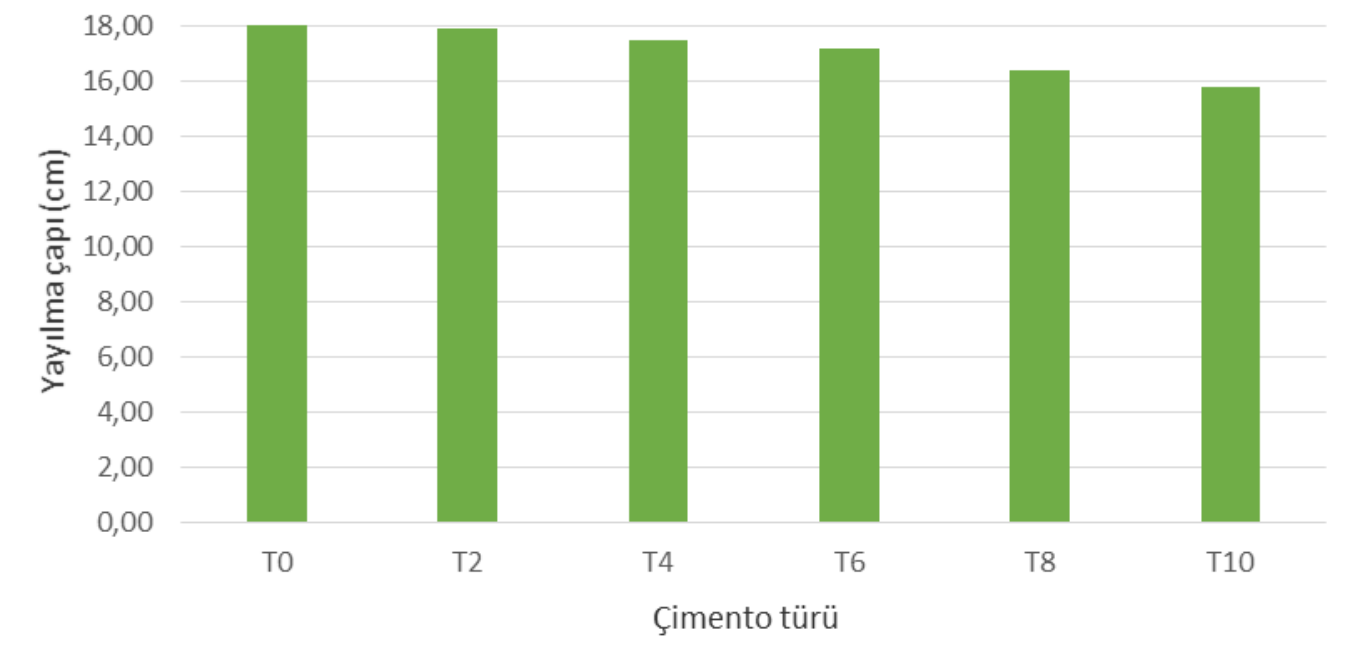

Şekil 4. Tezek külü ikameli çimento harçlarının yayılma değerleri

Tezek külü ikameli tüm numunelerin referans harcına göre daha düşük yayılma değerine sahip olduğu, numunelerin yayılma ilişkilerinin $\mathrm{T} 0>\mathrm{T} 2>\mathrm{T} 4>\mathrm{T} 6>\mathrm{T} 8>\mathrm{T} 10$ şeklinde sıralandığ 1 gözlemlenmiştir. Bu sıralama çimento yoğunluğunun, tezek külü yoğunluğundan fazla olması ile açıklanabilir. Ayrıca karışım yoğunluğunun azalması yayılma tablası yayılma değerini, dolayısıyla da işlenebilirliği azaltmıştır [14]. Tezek külü ikameli çimento harçlarının birim hacim ağırlı̆̆ı deney sonuçları Şekil 5'de verilmiştir.

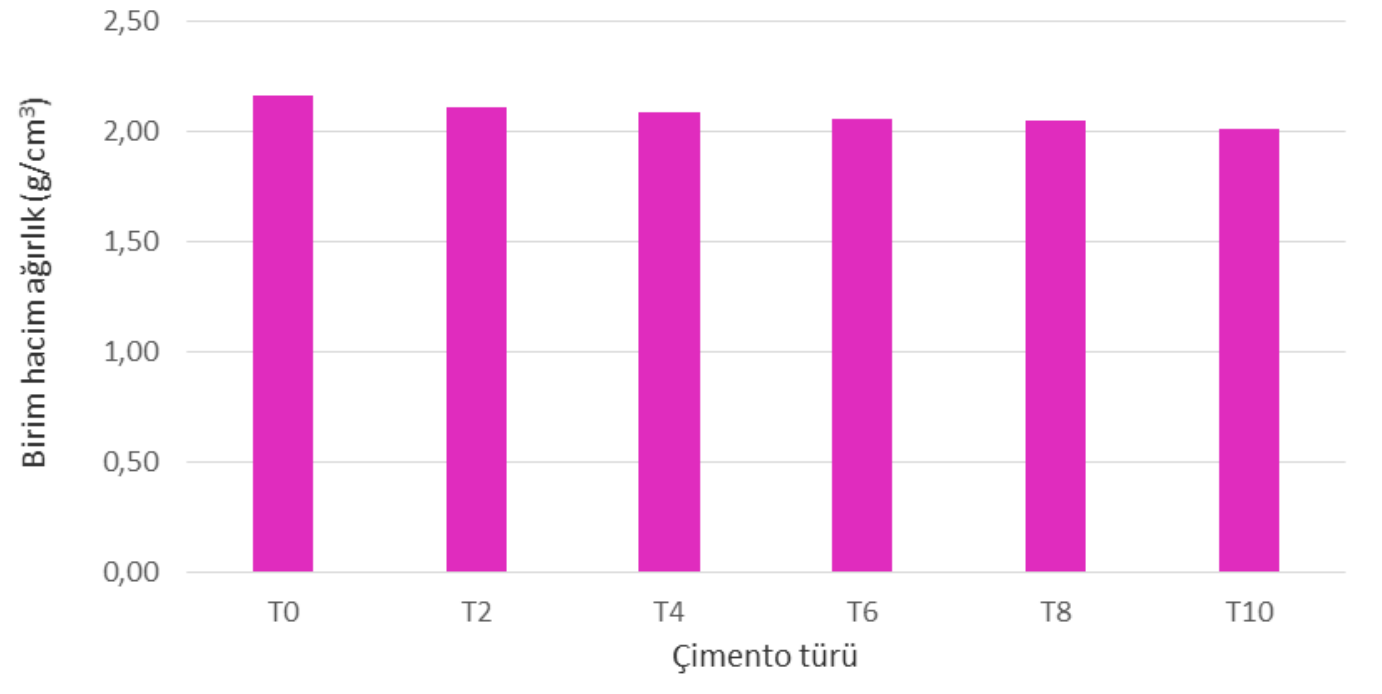

Şekil 5. Tezek külü ikameli çimento harçlarının birim hacim ağırlıkları

Numuneler üzerinde yapılan birim hacim ağırlık deney sonuçlarına göre, en ağır örneğin T0 şahit örneği olduğu ve tezek külü ikameli harçların birim hacim ağırlıklarının sırasıyla T0>T2>T4>T6>T8>T10 şeklinde olduğu belirlenmiştir. Tezek külü ikame oranı arttıkça numunelerin birim hacim ağırlıkları azalmıştır. Buradaki durum karışıma giren çimento yoğunluğunun $\left(3.12 \mathrm{~g} / \mathrm{cm}^{3}\right)$ ikame edilen tezek külü yoğunluğundan $\left(2.52 \mathrm{~g} / \mathrm{cm}^{3}\right)$ 
daha fazla olması ile açıklanabilir. Tezek külü ikameli çimento harçlarının TS EN 196-1 [11] standardına göre yapılan 2 ve 28 günlük eğilme ve basınç dayanımı deney sonuçları Şekil 6 ve Şekil 7’de verilmiştir.

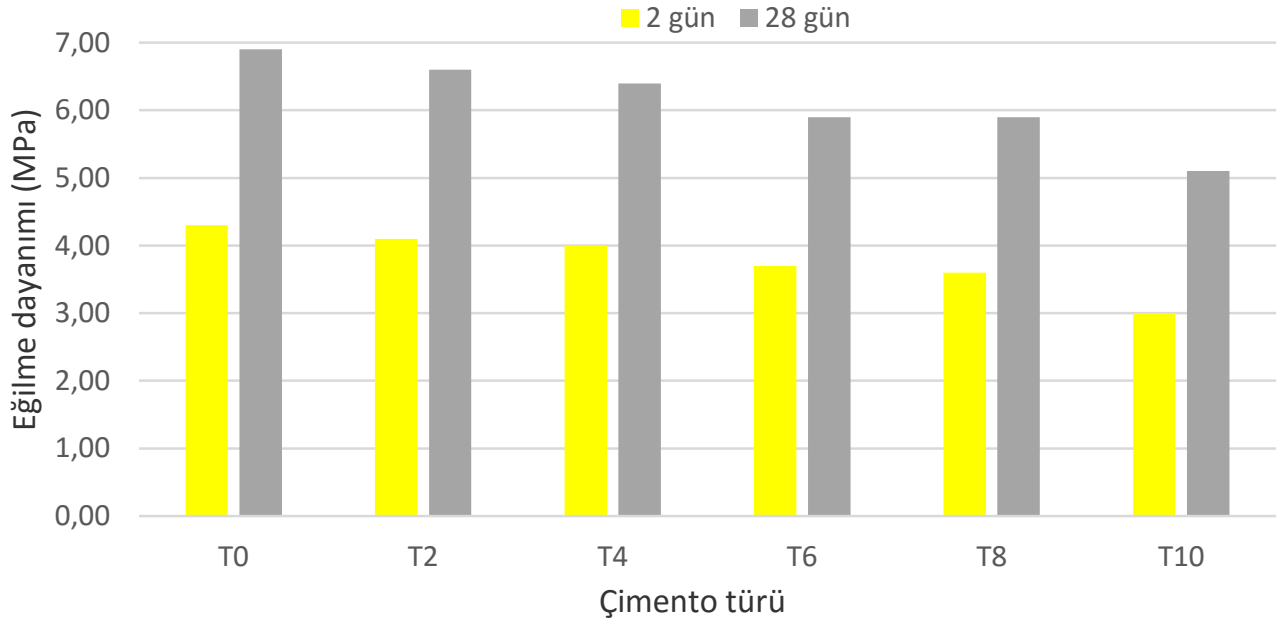

Şekil 6. Tezek külü ikameli çimento harçlarının 2-28 günlük eğilme dayanımları

$$
\square 2 \text { gün } \square 28 \text { gün }
$$

60,00

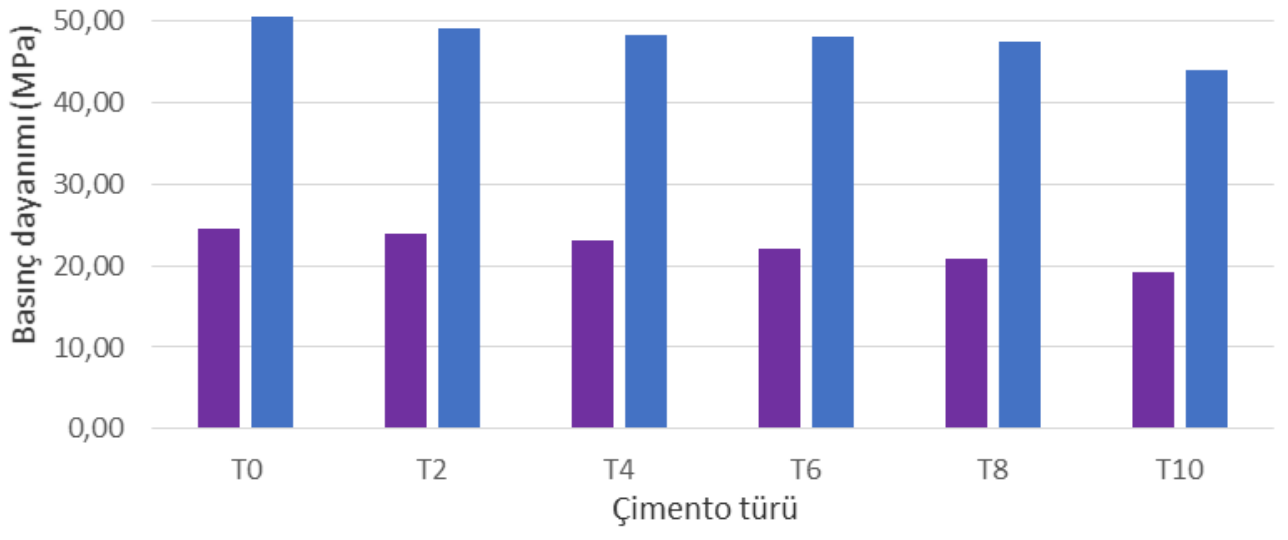

Şekil 7. Tezek külü ikameli çimento harçlarının 2-28 günlük basınç dayanımları

Tezek külü ikameli harçlar arasında hem 2 günlük hem de 28 günlük en yüksek basınç ve eğilme dayanımı özelliğine sahip örneğin T0 şahit numunesi olduğu, basınç ve eğilme dayanımı performanslarının sırasıyla T0 $>$ T2 $>$ T4 $>$ T6 $>$ T8 $>$ T10 şeklinde sıralandığı gözlemlenmiştir. Dolayısıyla tezek külü ikamesi ile basınç ve eğilme dayanımı performansının düştüğü söylenebilir. T10 numunesinin TS EN 197-1 [13] CEM I 42.5 R tipi çimento için belirtilen 2 günlük erken dayanımının en az $20 \mathrm{MPa}$ olması gerekirken tezek külü ikamesi ile bu değer 19.30 MPa' a düşmüştür. Dolayısıyla \%10 tezek külü ikameli çimentolar TS EN 197-1 [13] standardın da belirtilen 2 günlük dayanım kriterini sağlamamaktadır. Bununla birlikte, \%8'e kadar ikame yapılan numunelerin (T0, T2, T4, T6 ve T8) tezek külü ikamesine rağmen, TS EN 197-1 [13] standardında CEM I 42.5 R tipi çimento için belirtilen dayanım kriterlerini sağladığı tespit edilmiştir. 


\section{IV.SONUÇLAR}

$\mathrm{Bu}$ çalışmada tezek külü ikameli çimento harçlarının mühendislik özellikleri araştırılmıştır. Yapılan çalışma sonucunda elde edilen bilgiler aşağıda özetlenmiştir.

- Kimyasal analiz sonuçlarına göre tezek külünün bağlayıcıllk özelliği çok yüksek olan silisi yüksek miktarda içerdiği ve $\mathrm{SiO}_{2}+\mathrm{Al}_{2} \mathrm{O}_{3}+\mathrm{Fe}_{2} \mathrm{O}_{3}$ oranın \%76.24 ile TS 25 [16] standardında belirtilen puzolanik malzeme uygunluk değeri kriterinin üzerinde olduğu belirlenmiştir.

- 10 ikameye kadar üretilen tezek külü ikameli çimento hamurlarının, TS EN 197-1 [13] standardına göre sınır değer olan $10 \mathrm{~mm}$ genleşme sınırını aşmadığı belirlenmiştir.

- Çimento içerindeki tezek külü miktarı \%10 ikameye kadar arttıkça priz sürelerinin uzadığı ancak TSEN 196-3 [10] standardına göre bu sürelerin sınır değerler içerisinde kaldığı belirlenmiş̧ir.

- Tezek külü ikameli çimentolarda, tezek külü miktarı arttıkça, birim hacim ağırlığın, eğilme ve basınç dayanımı ile işlenebilme özelliğinin azaldığı belirlenmiştir.

- Üretilen numunelerden sadece \%10 ikameye sahip olan T10 numunesi TS EN 197-1 [13] standardın da CEM I 42.5 R tipi çimento için belirtilen 2 günlük dayanım kriterini sağladığı belirlenmiştir.

- Tezek külünün çimento içerisine en fazla \%8 oranına kadar ikame edilerek kullanılması önerilir.

- Tezek külünün puzolanik özelliğini net bir şekilde ifade edebilmek için en azından 56 günlük ve daha ileriki yaşlarda elde edilen verilere göre değerlendirme yapmak gerekmektedir.

- Tezek külünün kalsine sıcaklığı ve tane boyutu; tezek külü ikameli çimentoların karakteristiklerini (özgül yüzey alanı, $\mathrm{SiO}_{2}$ bileşen oranı, özgül ağırlık değeri vb.) doğrudan etkileyeceği için bundan sonraki yapılacak çalışmalarda kalsine sıcaklığı ve tane boyutu özelliklerinin dikkate alınması önerilir.

- Ayrıca, tezek külü ikameli harçların termal özelliklerinin ve uzun süreli performans özelliklerinin araştırılmasının faydalı olacağı düşünülmektedir.

\section{KAYNAKLAR}

[1] Korkmaz, A. V. (2019). Çimento Üretiminde Kil Ham Maddesine Alternatif Olarak Çamurtaşının Kullanılabilirliği. Bilimsel Madencilik Dergisi, 58 (1), 7-15.

[2] Dobiszewska, M. \& Beycioğlu, A. (2017). Investigating the Influence of Waste Basalt Powder on Selected Properties of Cement Paste and Mortar. IOP Conference Series: Materials Science and Engineering, 245 (2), 1-10.

[3] Rayaprolu, V. S. R. P. K. \& Raju, P. P. (2012). Incorporation of Cow Dung Ash to Mortar and Concrete. International Journal of Engineering Research and Applications (IJERA), 2(3), 580-585.

[4] Ojedokun, O. Y., Adeniran, A. A., Raheem, S. B. \& Aderinto, S. J. (2014). Cow Dung Ash (CDA) as Partial Replacement of Cementing Material in the Production of Concrete. British Journal of Applied Science \& Technology, 4(24), 3445-3454.

[5] Venkatasubramanian, C., Muthu, D., Aswini, G., Nandhini, G. \& Muhilini, K. (2017). Experimental Studies on Effect of Cow Dung Ash (Pozzolanic binder) and Coconut Fiber on Strengthproperties of Concrete. IOP Conference Series: Earth and Environmental Science, 1-6.

[6] Sruthy, B., Krishnan, A. G., Mathew, G. M. \& Raj, S. G. (2017). An Experimental Investigation on Strength of Concrete Made with Cow Dung Ash and Glass Fibre. International Journal of Engineering Research \& Technology (IJERT), 6(3), 492-495.

[7] Familusi, A. O., Adekunle, A. A., Badejo, A. A. \& Olomo, R. O. (2018). Waste Valorisatıon: Use of Cow Dung Ash as a Partal Replacement for Cement in Sandcrete Blocks. Proceedings of the 2018 International Conference on STEM: A Driving Force for Sustainable Development Tagged, 1-10. Abeokuta.

[8] Kumar, A. (2018). Partial Replacement of Cement with Fly Ash and Cow Dung Ash by Using Quarry Dust as a Fine Aggregate. International Journal of Engineering Science Invention (IJESI), 7(10), 1-11.

[9] Szymajda, A., Laska, G. \& Majewski, M. (2020). Characteristics of Ashes from the Combustion of Cow Dung Biomass. The 9th Innovations-Sustainability-Modernity-Openness Conference (ISMO'20), 1-3. Bialystok.

[10] TSE(Türk Standartları Enstitüsü), 2017. TS EN 196-3: Çimento Deney Yöntemleri-Bölüm 3: Priz Süreleri ve Genleşme Tayini. 
[11] TSE (Türk Standartları Enstitüsü), 2016. TS EN 196-1: Çimento Deney Metotları-Bölüm 1: Dayanım Tayini.

[12] TSE (Türk Standartları Enstitüsü), 2000. TS EN 1015-3: Kagir Harc1- Deney Metotları-Bölüm 3: Taze Harç Kıvamının Tayini (Yayılma Tablası İle).

[13] TSE (Türk Standartları Enstitüsü), 2012. TS EN 197-1: Çimento-Bölüm 1: Genel Çimentolar-Bileşim, Özellikler ve Uygunluk Kriterleri

[14] Kara, İ. B. (2020). Çay Endüstrisi Atık Küllerinin Beton Üretiminde Değerlendirilmesi. Düzce Üniversitesi Bilim ve Teknoloji Dergisi, 8(1), 983-992.

[15] Özdemir, İ. \& Koçak, Y. Pirinç Kabuğu Külü İkameli Çimentoların Fiziksel ve Mekanik Özelliklerinin Araştırılması. El-Cezerî Fen ve Mühendislik Dergisi, 7(1), 160-168.

[16] TSE (Türk Standartları Enstitüsü), 2008. TS 25: Doğal Puzolan (Tras)-Çimento ve Betonda KullanılanTarifler, Gerekler ve Uygunluk Kriterleri. 